\title{
20. Ein Beitrag zur frühzeitigen Diagnostik des Acusticustumors
}

\author{
Genkichi Torsuka und Eiji Sakata \\ Hals-Nasen-Ohrenklinik, Universität Tokio \\ Hideo TERAO \\ Neurochirurgischen Klinik, Städtischen Krankenhauses Tokio-Hirowo
}

Viele Fälle von Hirntumor haben Schwindel oder Ohrensausen als Hauptsymptome wie bei Acusticustumor otoneurologische Symptome. Es passiert nicht so selten, dass ein Acusticustumor oder Kleinhirntumor als Morbus Ménière oder Nervenschwerhörigkeit nur mit medikamentöser Therapie behandelt wird. Solche Symptome dürfen oft hinsichtlich der otoneurologischen Differentialdiagnose nicht vernachlässigt werden.

Wegen der Entwicklung der otoneurologischen Diagnostik kann man heutzutage ermöglichen, den Acusticustumor sehr frühzeitig zu diagnostizieren, wenn der Tumor auch in Meatus acusticus internus beschränkt vorhanden wäre.

Für die Diagnose des Acusticustumors können die Verfasser nur sagen, dass sich um das Verhalten der calorischen Erregbarkeit handele. Dann sind das Cochlearsymptom und das Herabsinken des Geschmackssinnes der vorderen 2/3 von der Zunge von grosser Bedeutung. Die Störung der Cornealsensibilität, Atypische Befunde des Spontan- und Provokations- Nystagmus und die Zunahme des Liquoreiweiss ergänzen richtige Diagnose. Weitere diagnostische Hilfsmittel sind unseres Erachtens die röntgennologische Untersuchung.

Nach all diesen Symptomen haben wir den zeitlichen Verlauf des Acusticustumors in 5 Chronologie gegliedert und betont, dass die Diagnose in dem Stadium Null sehr wichtig und auch möglich ist.

\section{Acoustic Nerve Tumor}

-An analysis of symptoms and sings in an attempt

to establish early diagnosis-

\author{
Hiroshi Abe, Takashi Ohwada, Kazuyoshi Ueno, Kenzoh YadA \\ and Mitsuo Tsuru \\ Department of Neurosurgery, Hokkaido University School of Medicine
}

The present report is based on an analysis of early symptoms and signs seen in 31 cases of acoustic neurinoma which were treated at the Department of Neuro- 
surgery, Hokkaido University Hospital during the past 9 years.

Although in 22 cases or $71 \%$ of the group, the initial symptoms were either tinnitus or hearing disturbance, $29 \%$ of the patients noticed symptoms due to adjacent cranial nerve (Vth, VIth and VIIth) disturbance prior to the symptoms originating from the acoustic nerve.

At the time of admission, most of the patients showed enough clinical signs and symptoms to establish diagnosis without aids of X-Ray or other laboratory studies.

Among the 31 cases, there were 3 cases of which size were smaller than $2.5 \mathrm{~cm}$ in diameter. The constant signs seen in these 3 cases were Vth, VIIth and VIIIth cranial nerve signs.

Concerning to the otologic examination, although hearing loss was not observed in 3 cases out of 31 , caloric test was positive in all the cases. Nystagmus was noted in all the cases except for one. Therefore, we feel that the caloric test is the most valuable single examination for the early diagnosis of the acoustic tumors.

By analyzing the course of the disease, we failed to find out any constant order of the appearance of various symptoms. Only $42 \%$ of the cases followed the Cushing's chronology.

As for radiological examinations, plain skull films are seldom useful in early diagnosis. Vertebral angiography gives information only when the size of the tumor becomes larger than $2.5 \mathrm{~cm}$ in diameter. We feel that the cisternography using positive contrast medium is the most valuable single radiological examination available.

\title{
22. Removal of Acoustic Neurinoma through Transtemporal Approach
}

\author{
Hideo Terao and Yasushi Thukamoto \\ Dept. of Neurosurgery, Hiroo Metroporitan hospital \\ Genkichi Totsuka and Eiji SaKaTA \\ Dept. of Otolaryngeology, Faculty of Medicine, Univ. of Tokyo
}

Dept. of Otolaryngeology, Faculty of medicine Univ. of Tokyo. Under the development of the microsurgery and of diagnostic methods for acoustic neurinomas, the temporal approach for this tumor has stimulated the interests of neurosergeans and otologists.

We have experienced 3 removals of acoustic neurinomas through the transtemporal approach.

The first case was so called "ear tumor." Operation was performed by the middle fossa extradural approach. A pea-sized neurinoma was located within the 